\title{
Outward FDI and institutional factors: Malaysian experience
}

\begin{abstract}
This paper aims to investigate the role of home country institution in affecting outward FDI from Malaysia using data spans from 1980 to 2012. The model specification is examined in autoregressive distributed lag (ARDL) bounds testing framework. The empirical evidence reveals that GDP, exchange rate, openness to trade, and corporate tax rate are the key drivers of outward FDI from Malaysia. This portrays that internationalization strategy of firms is not only relied on home macroeconomic environment, but also home institution. More importantly, corporate tax rate, as one of the institution factors, is positively related to outward FDI which signifies that high tax rate would prompt local firms to engage in investment abroad as a sign of escape response. This reflects that international expansion appears to be exit strategy from home country instead of entry strategy into foreign markets. The findings have some important implications on internationalization strategy of firms.
\end{abstract}

Keyword: Outward FDI; Institution; Escape Response; ARDL; Malaysia 